\title{
Gambaran struktur kulit hewan coba pada beberapa interval waktu postmortem
}

\author{
${ }^{1}$ Kartika A. Abeng \\ ${ }^{2}$ Sonny J. R. Kalangi \\ ${ }^{2}$ Sunny Wangko
}

\author{
${ }^{1}$ Kandidat SkripsiFakultasKedokteranUniversitas Sam Ratulangi Manado \\ ${ }^{2}$ Bagian Anatomi-Histologi Fakultas Kedokteran Universitas Sam Ratulangi Manado \\ Email: amandakartika2@gmail.com
}

\begin{abstract}
This study aimed to obtain the postmortem histological changes of the skin. This was an experimental-descriptive study using one pig as model. Samples were taken at several time intervals during 24 hours postmortem: 0 hour; 1 hour; 2 hours; 3 hours; 4 hours; 5 hours; 6 hours; 7 hours; 8 hours; 9 hours; 10 hours; 11 hours; 11 hours; 12 hours; and 24 hours. The results showed that histological changes of the skin began to occur in 4 hours postmortem in the form of epidermal congestion. In 5 hours postmortem Meissner corpuscles could not be identified anymore. In 7 hours postmortem most cells of epidermis showed karyolysis. In 8 hours postmortem Langerhans cells could not be identified anymore. In 9 hours postmortem structure epidermal cells can not be identified. In 24 hours postmortem, borders of the epidermis and dermis could not be identified. Conclusion: Postmortem changes in the histological structure of the skin were consecutively: epidermal congestion, Meissner corpuscles and Langerhans cells could not be identified, and karyolysis of epidermal cells. In 24 hours postmortem, most of the skin architecture was unidentified. It is expected that these postmortem histological changes of the skin could be applied in the medicolegal investigation especially for death cases of less than 24 hours postmortem, therefore, further studies are needed.
\end{abstract}

Keywords: structure, skin, postmortem

\begin{abstract}
Abstrak: Penelitian ini bertujuan untuk mendapatkan perubahan gambaran histologik kulit postmortem. Penelitian ini menggunakan metode deskriptif eksperimental dengan babi sebagai hewan coba. Sampel jaringan kulit diambil pada interval waktu 0 jam; 1 jam; 2 jam; 3 jam; 4 jam; 5 jam; 6 jam; 7 jam; 8 jam; 9 jam; 10 jam; 11 jam; 12 jam; dan 24 jam postmortem. Hasil penelitian memperlihatkan perubahan struktur mulai tampak 4 jam postmortem berupa kongesti epidermis kulit. Pada 5 jam postmortem badan Meissner tidak dapat diidentifikasi lagi. Pada 7 jam postmortem sebagian sel-sel epidermis mulai kariolisis. Pada 8 jam postmortem sel Langerhans tidak dapat diidentifikasi lagi. Pada 9 jam postmortem struktur selsel epidermis tidak dapat diidentifikasi. Pada 24 jam postmortem batas epidermis dan dermis tidak dapat diidentifikasi. Simpulan: Perubahan struktur kulit postmortem yang dimulai pada 4 jam postmortem ialah sebagai berikut: kongesti epidermis, badan Meissner dan sel Langerhans tidak dapat diidentifikasi, dan kariolisis sel-sel epidermis. Pada 24 jam postmortem arsitektur kulit telah menjadi tidak tegas. Penelitian ini diharapkan dapat diaplikasikan untuk kepentingan medikolegal, terutama pada kematian $\leq 24$ jam.
\end{abstract}

Kata kunci: struktur histologik kulit, postmortem

Kulit ialah organ tunggal dan terberat pada tubuh manusia dengan ukuran Seluruh kulit beratnya sekitar $16 \%$ berat tubuh, pada orang dewasa sekitar 2,7 - 3,6 kg dan 
luasnya sekitar $1,5-1,9$ meter persegi. ${ }^{1-2}$

Fungsi kulit antara lain memantau lingkungan dan berbagai mekanoreseptor dengan lokasi khusus di kulit terhadap interaksi tubuh dengan objek fisis dan mekanik seperti paparan sinar matahari yang dapat terjadi secara akut yaitu timbulnya reaksi terbakar sunburn dan pigmentasi, maupun kronis yang dapat menyebabkan penuaan dini dan pertumbuhan tumor.-5

Memperkirakan saat kematian yang mendekati ketepatan mempunyai arti penting khususnya bila dikaitkan dengan proses penyidikan. Untuk dapat memperkirakan saat kematian perlu diketahui perubahan-perubahan yang terjadi pada tubuh seseorang yang meninggal dunia, dan juga faktor-faktor apa saja yang berperan di dalam terjadinya perubahan-perubahan tersebut. ${ }^{6-7}$

Perubahan kulit yang terjadi selama interval postmortem digunakan untuk memperkirakan waktu kematian dalam kondisi yang berbeda Namun, perubahan histologis postmortem kulit jarang dianalisis secara sistematis. ${ }^{8-9}$

Pengertian proses postmortem dalam penelitian ini merupakan perlakuan terhadap ternak setelah dimatikan. Berdasarkan latar belakang di atas, penulis tertarik untuk melakukan penelitian gambaran struktur kulit hewan coba pada beberapa interval waktu postmortem.

\section{METODE PENELITIAN}

Penelitian ini bersifat deskriptifeksperimental dan dilakukan di Laboratorium Histologi Fakultas Kedokteran Universitas Sam Ratulangi dan Pusat Diagnostik Patologi Anatomi Manado. Subjek penelitian yaitu 1 ekor babi dengan kriteria: Berat badan15 kg, secara fisik aktif, sehat, dan tanpa luka. Pengambilan sampel kulit dilakukan sebagai berikut: Area kulit babi dicukur rambutnya kemudian dicuci dengan alkohol 70\%. Luka insisi dibuat melintang, panjang $3 \mathrm{~cm}$, dan kedalaman $1 \mathrm{~cm}$. Luka insisi dibuat setiap interval 1 jam dimulai pada 0 jam sampai 24 jam.

\section{HASIL PENELITIAN}

Gambaran struktur kulit yang tampak pada 0 jam postmortem dapat dilihat pada Gambar 1. Pada bagian epitel dapat diidentifikasi epidermis, sel Langerhans tampak jernih. Pada papila dermis terdapat badan Meissner yang tampak pucat. Pada hipodermis serat kolagen tampak bergelombang karena bersifat lentur (pembesaran 40x mikroskop cahaya). Perubahan paling awal terlihat pada 4 jam postmortem berupa kongesti epidermis (Gambar 2).

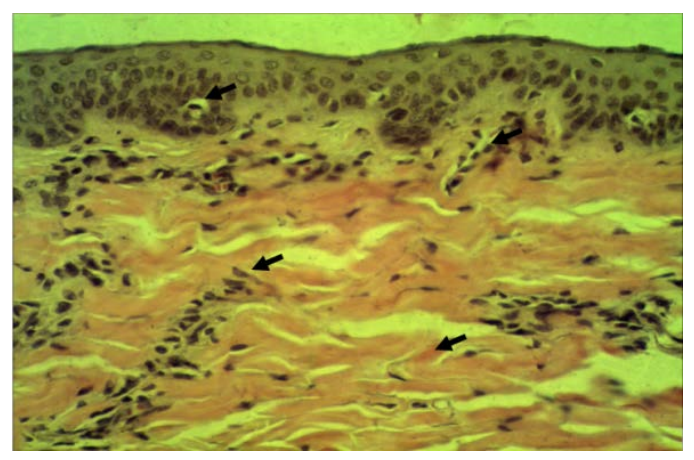

Gambar 1. Mikroskopik potongan kulit

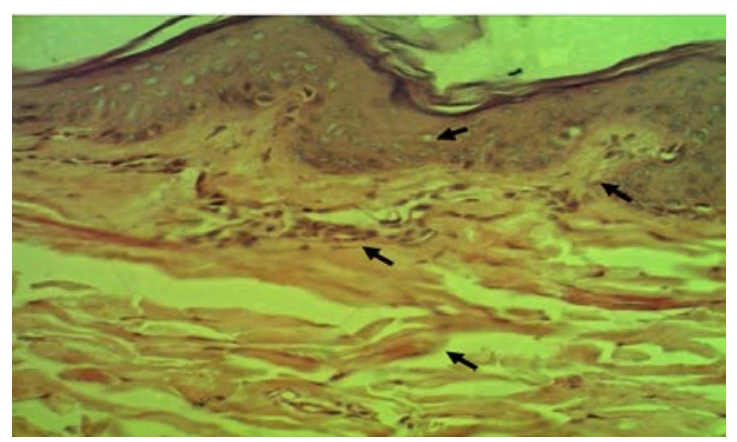

Gambar 2. Mikroskopik potongan kulit babi pada daerah yang diambil 4 jam postmortem. Tampak kongesti epidermis. Sel Langerhans dan badan Meissner di papila dermis, masih terlihat. Pada hipodermis serat kolagen tampak renggang (Pembesaran 40x mikroskop cahaya).

Badan Meissner tidak dapat diindentifikasi pada 5 jam postmortem (Gambar 3). Sebagian sel epidermis mulai kariolisis 7 jam postmortem (Gambar 4). Sel Langerhans tidak dapat diidentifikasi pada 8 jam postmortem (Gambar 5). 
Struktur sel epidermis tidak dapat diidentifikasi pada 9 jam postmortem (Gambar 6). Batas epidermis dan dermis tidak dapat diidentifikasi pada 24 jam postmortem (Gambar 7).

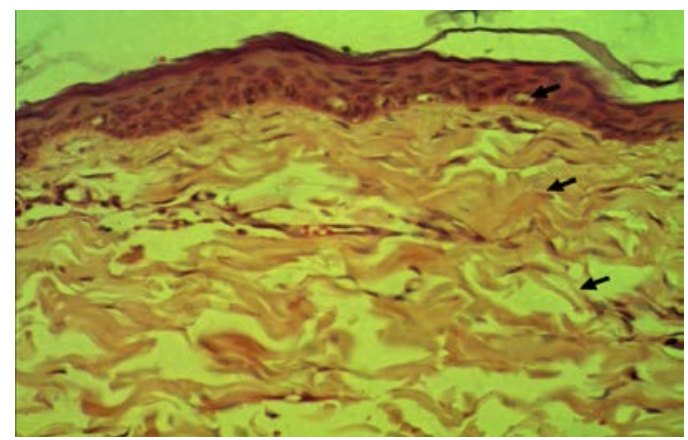

Gambar 3. Mikroskopik potongan kulit babi pada daerah yang diambil 5 jam postmortem. Kongesti epidermis pada. (Pembesaran 40x mikroskop cahaya)

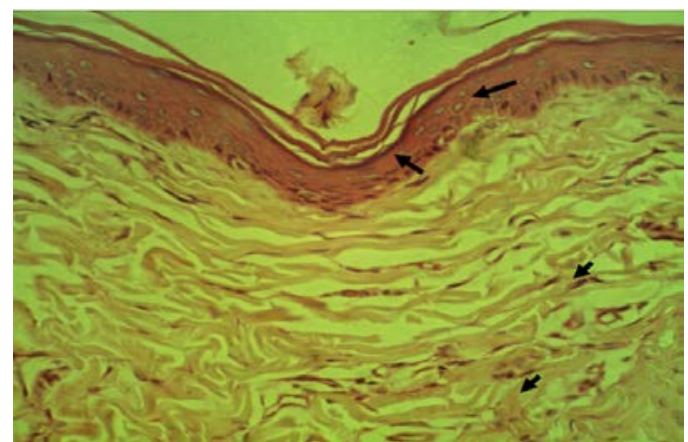

Gambar 4. Mikroskopik potongan kulit babi pada daerah yang diambil 7 jam postmortem. sebagian sel-sel epidermis mulai kariolisis. (Pembesaran 40x mikroskop cahaya)

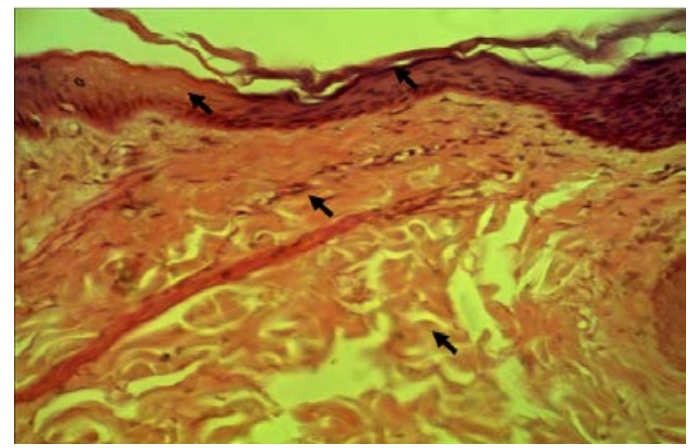

Gambar 5. Mikroskopik potongan kulit babi pada daerah yang diambil 8 jam postmortem. Sel Langerhans tidak dapat diidentifikasi. (Pembesaran 40x mikroskop cahaya)

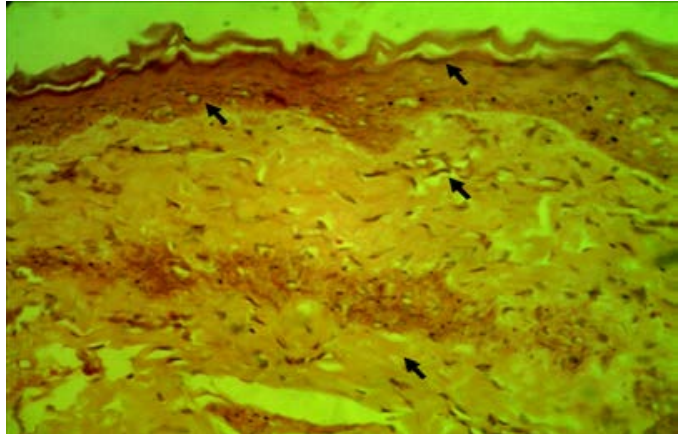

Gambar 6. Mikroskopik potongan kulit babi pada daerah yang diambil 9 jam postmortem. struktur sel-sel epidermis tidak dapat diidentifikasi (Pembesaran 40x mikroskop cahaya).

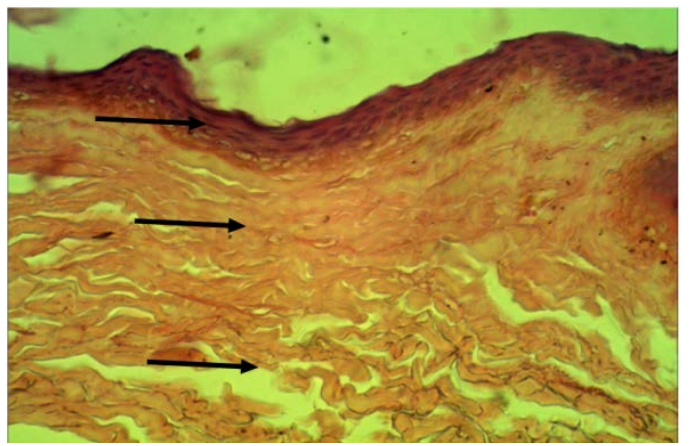

Gambar 7. Mikroskopik potongan kulit babi pada daerah yang diambil pada 24 jam postmortem. Arsitektur kulit telah menjadi tidak tegas. (Pembesaran 40x mikroskop cahaya)

\section{BAHASAN}

Penelitian ini dilakukan untuk melihat gambaran histologik struktur kulit pada hewan coba, yaitu satu ekor babi domestik Sus scrofa dengan berat badan $15 \mathrm{~kg}$. Dalam keadaan normal adanya perubahanperubahan yang terjadi setelah kematian pembusukan mulai tampak kira-kira 24 jam postmortem. Pembuluh darah bawah kulit akan melebar, hijau kehitaman, kemudian kulit terkelupas, menyebabkan pembengkakan tubuh menyeluruh, terutama pada jaringan longgar.

Rambut dan kuku mudah tercabut, seluruh wajah membengkak warna ungu kehijauan. Pada 36-48 jam postmortem pembusukan lebih cepat bila suhu dan kelembaban udara cukup. Selain itu epitel kulit, kuku, rambut kepala, aksila dan pubis mudah dicabut dan dilepaskan oleh karena adanya desintegrasi pada akar rambut. 
Pada penelitian ini didapakan perubahan struktur mulai tampak 4 jam postmortem berupa kongesti epidermis kulit. Pada 5 jam postmortem badan Meissner tidak dapat diidentifikasi lagi. Pada 7 jam postmortem sebagian sel-sel epidermis mulai kariolisis. Pada 8 jam postmortem sel Langerhans tidak dapat diidentifikasi lagi. Pada 9 jam postmortem struktur sel-sel epidermis tidak dapat diidentifikasi. Pada 24 jam postmortem batas epidermis dan dermis tidak dapat diidentifikasi. Badan Meissner yang merupakan reseptor taktil mengalami nekrosis lebih awal dibandingkan sel Langerhans yang merupakan sel jaringan ikat.

\section{SIMPULAN}

Perubahan struktur kulit postmortem yang dimulai pada 4 jam postmortem ialah sebagai berikut: kongesti epidermis, badan Meissner dan sel Langerhans tidak dapat diidentifikasi, dan kariolisis sel-sel epidermis. Pada 24 jam postmortem arsitektur kulit telah menjadi tidak tegas.

\section{DAFTAR PUSTAKA}

1. Perdanakusuma SD. Anatomi Fisiologi Kulit dan Penyembuhan Luka. [cited 20156 Jan 5]. Available from: http://www.fk.unair.ac.id/attachments /1705_ANATOMI\%20FISIOLOGI\%
20KULIT\%20DAN\%20PENYEMB UHAN\%20LUKA\%20Agustus\%202 007.pdf

2. Mescher AL. Histologi Dasar Junqueira (12th ed). Jakarta: EGC, 2011; p. 309-17.

3. Corwin JE. Buku Saku Patofisiologi (3rd ed, revised). Jakarta: EGC, 2007; p. 99-101, 387. [cited 20156 Jan 5]. Available from: https://books.google.co.id/books

4. Gartner PL, Hiatt LJ. Atlas Berwarna Histologi (5th ed). Jakarta: Binarupa Aksara, 2012; p. 274.

5. Sloane E. Anatomi dan fisiologi. Jakarta: EGC, 1995; p. 86. [cited 20156 Jan 5]. Available from: https://books.google.co.id/books

6. Melisa L. Jenis-jenis stimulus dan reseptornya. [cited 20156 Jan 5]. Available from:: https://www.scribd.com/doc/5937364 5/LTM-2-Leslie

7. Arie KIA. Langerhans cell histiocytosis. [cited 20156 Jan 5]. Available from: https://www.scribd.com/doc/1290638 51/Langerhan-Cell-Histiocytosis

8. The skin of the domestic pig. The Journal of Investigative

Dermatology. 1964;43:11-21; doi:10.1038/jid.1964.110.

9. Montagna W, Jeung SY. [cited 20156 Jan 5]. Available from: http:// www.nature.com/ jid/ journal/ v43/ n1/ abs/ jid.1 964110a. 